\title{
The Role of Guerilla Marketing for Consumer Buying Behavior in Clothing Industry of Pakistan using Structural Equation Modeling (SEM)
}

\author{
Raheel Farooqui *
}

\begin{abstract}
The study examines the impact of viral, street, stealth, ambient, and ambush marketing on consumer buying behavior towards the clothing industry in Karachi, Pakistan. The study has used structural equation modeling for data analysis while purposive sampling technique has been used and collected 247 sample size based on the estimation of Soper (2018). The results have shown that street marketing, stealth marketing and ambush marketing, as components of Guerilla marketing, have considerable effect on consumers' buying behavior towards clothing products in Karachi, Pakistan. However, viral marketing and ambient marketing were found to have none relationship with consumers' buying behavior towards clothing products. In this regards, the study concluded that people in Karachi city of Pakistan don't pay much attention towards the authenticity of information they are receiving, they show interest in fake news, blogs, social networking sites etc. which can be used as the powerful tools of stealth marketing. While people responds more on unconventional ways, like placing ads where people read, physically interacting with people, distributing samples and wrap advertising. Henceforth, on the basis of results and findings, the study also provides some managerial and practical implications as well as future research directions.
\end{abstract}

Keywords: Guerilla Marketing, Consumer Buying Behavior, Clothing Industry, CB-SEM, Karachi.

\section{Introduction}

Advertisement is an activity that is significantly associated with the sales and profitability of a company (Kumar, Choi, \& Greene, 2017). Several companies invest in advertisement activity as to enhance the sales figure and also to boost the market share with the dynamic credibility, while advertising activities has significantly impacts on the sales and on the profitability of a company. With the passage of time competition, human intelligence and capital discover more creative and dynamic approaches of marketing and advertisement of the product and services of a company (Velema, Vyth, Hoekstra, \& Steenhuis, 2018). At this pace of technology, organizations are discovering several techniques and instrument to do dynamic marketing communication with target audiences, allowing companies to be more competitive.

\footnotetext{
*Lecturer, Bahria University, Pakistan. Email: raheel_farooqui@hotmail.com
} 
In 1989, Jay Levinsondiscovers Guerrilla marketing techniques to be the most costeffective and easiest ways to approach target audiences in the common market (Levinson, 1989). Guerrilla marketing is usually adopted by small business units to endorse their services and products to the targeted audience in common market by utilizing minimum budget spending advertisement strategy methods (Kelly, 2015).Several types of Guerrilla marketing are emphasized, which include ambient marketing, ambush marketing, stealth marketing, viral marketing and street marketing. In this phase of competitive and compatible challenges, the clothing industry is moving towards globalized modern standards. According to Mifsud (2014), small and medium enterprises proposed the guerrilla marketing based on the human psychology, brand equity, and business wealth to enhance the aggressive compensation in a common market.

The customers are well aware about the surprising effect of guerrilla marketing techniques (Ahmad et al., 2014; Iqbal \& Lohdi, 2015; Sharif \& Butt, 2017). It diversifies the consumer positive perception towards a brand via outdoor advertisement promotional campaign.Pakistani clothing brands such as; Gul Ahmed, Al Karam, NishatLinen, Firdous, Bonanza, House of Ittehad, AsimJofa, Five Star, Sana Safinaz, Crescent and etc. are also focusing towards the guerrilla marketing approaches. Gul Ahmed, Al Karam, Khadi, etc. are applying guerrilla marketing as a marketing strategy to make changes in brand wealth and productivity of business (Soomro, 2015). Promotional camping of these famous garments and textile companies builds strong awareness and loyalty in the mind of the target audience. Currently, Gul Ahmed Textile Company is totally not relying on the conventional or unconventional marketing techniques such as print and electronic media ads. For example, Gul Ahmed Corporation launches a product line called 'Idea' to advertise about the product via 'Marketing truck' around the city with creative and clear posters.

In the old era of market, the companies had few brands and high competition in the common market; to retain the company's productivity and profitability they tried to adopt a new product line in the market (Ghanbari \& Ghanbari, 2017). But in this current era of technology and communication the competition and service and product line is very high, all are quite busy to win the maximum market share as the company credibility and revenue. The alternative advertising modes based on the unconventional marketing strategies, it is really full of imagination and energy of convincing (Tam \& Khuong, 2015). Guerrilla marketing approaches are about to custody the consumer by surprise and indelible impression; while; it also creates numerous amounts of social crowed buzz. Promotional strategies of guerrilla marketing are assumed to make a far further priceless idea with customers in assessment to supplementary conventional forms of marketing and advertisement. Marketing and adverting is actually a technique of promotion, where the marketer develops the strategies according to the 4Ps (Product, Price, Place, Promotion) of a brand (Dempsey, 2016). With this dynamic method a company targets the common market of the audiences and introduce about their service or products (brand).

The study examines the impact of viral, street, stealth, ambient, and ambush marketing on consumer buying behavior towards the clothing industry in Karachi, Pakistan. The clothing brands have to apply guerrilla marketing and advertisement in the field of promotion or any other strategies offered by companies, and to discover the updated techniques of guerrilla marketing in the clothing industry of Pakistan. Therefore, the study has the 
following research question for analysis and findings.

RQ: What is the impact of different Guerrilla marketing tactics on the consumer buying behavior towards clothing brands in Karachi, Pakistan?

This study was conducted to collect information in order to identify the influence of guerrillas marketing on consumer buying behavior in an appropriate way. Juxtapose, a few studies have been conducted in recent years that examine the impact of guerrilla marketing on consumer's buying behavior of Karachi, Pakistan with respect to apparel industry. This study aims to provide the stimuli and how the target market reacts to it and also what they require in an appropriate way. This develops a new way for apparel companies to be able to stimulate and integrate their product for their specific target markets in a more appropriate approach, both domestically and internationally. Today, guerrilla marketing becomes one of the modest ways to understand and approach consumers and to fulfill their needs. The loss and cost of advertisement is reduced through this advertisement and consumers are aware regarding the high level product. By examining the direct impact of guerrilla marketing, a company can attempt to duplicate the practices of guerrilla-marketing of integrate a novice one in order to temper off competition at all levels.

The scope of the study is to emphasize the gap on Pakistan apparel industry that assists in order to demonstrate the impact of guerrilla marketing on consumer buying behavior and that will further aid to understand the marketing of apparel products in Karachi City.

The different guerrilla marketing tactics are typically developed and executed to arouse emotions, since an important focus of guerrilla marketing is to use emotional appeal to affect the consumer on a deeper level as Theory standard linear models of consumer designs making helps consumer in Fashion volatility makes demand for clothing accessories very unpredictable compared with any other sectors such as groceries where steady consumer demand patterns exists. Similarly generic market research methods are sufficient to describe and explain the information gathering and analyses that underpin wider fashion marketing activity. It is also believed that the gap Guerrilla marketing adds a further dimension in a unique way to understand consumers predicting their wants in unconventional ways as it make perception changes quickly which conventional marketing doesn't.

\section{Theoretical Background and Hypotheses Development}

In this segment, the conceptual background signifies relevant studies hypotheses. First, significant evaluation of the literature on Guerilla marketing is carried out. Then, this segment offers to explain the critical studies on guerrilla marketing and its types such as viral ,ambient ,stealth, ambush and street marketing aspects involved in manufacturing clothing brands effectiveness. Third, it considers the outcomes of guerrilla advertising on customers' cognitive, affective and conative responses. Moreover, it presents the constructs measured and the five research hypotheses formalized based upon Hutter and Hoffmann's model Framework. 


\section{Literature Review}

\section{Guerrilla Marketing and Consumer Buying Behavior}

Guerrilla marketing techniques are ideal for small and medium business ventures, which approach a large number of audiences without breaking the bank. This method of promotion is also used by large companies in ordinary marketing campaigns to complement continuing crowed media campaigns (Tam \& Khuong, 2015). Individual's ventures have also adopted these marketing techniques as an approach to be able for additional business opportunities. Promotional strategies of guerrilla marketing are assumed to make a far further precious thought with customers in comparison to supplementary traditional forms of marketing and advertisement (Iqbal \& Lohdi, 2015). At this pace of competition, the first stroke to be taken by the guerilla marketers is to overwhelm this hub of the media mass lacking greater than ever any cost advertising and promotion in sales, and second, to enhance the profits of business, not from direct sales factors such as; hot sale offer cost-promotion-discount etc. The most significant motive is the media channels caused by innovative business cycle that the alternative to advertisements and promotions known for their brand (service or product) to their target audience (Ghanbari \& Ghanbari, 2017). The old companies enhance their previously existed promotional and advertising activities in strength to compete with the new companies and their brands. Several companies designed guerrilla marketing strategies for their brands, but they did not capture the maximum market as they designed, the reason was they did not select the accurate place, audience demands and presentation approaches.

\section{Viral Marketing and Consumer Buying Behavior}

The ultimate phenomenon of clothes shopping has undergone massive change in terms of consumer buying behavior and format, steering a revolution in the wholesale shopping (Scott, 2015). Consumer buying behavior is the most unique attribute for the marker. As it is the one major area of focus before the making or planning of an ad. Every ad is based on the past experience and perception of the consumers about the brand. To better recognize consumer buying decisions, an analysis between perceived brand's characteristics such as taste, quality, environmental concerns and price is undertaken (Waheed \& Jianhua, 2018). Guerrilla marketing has an impressive blow on consumer buying behavior and it is also appropriate for most companies and as an alternative of hypothesis, experience plus finding that would be based upon the psychology of marketer. It builds with the basic elements, such as sociology, psychology, social psychology and economics anthropology. It also stabs to assess the inspiration in the mind of the consumer; it links from their fellow, friends, family, reference and society in common.

The fundamental standard of viral message, though, relics the traditional word of mouth pattern that is now facilitated by the Internet. Companies start to realize the dynamic assessment of the Internet communication as a primary tool of the guerrilla marketing and communication platform (Schulze, Schöler, \& Skiera, 2014). They are individually opening to influence substitute approaches of marketing practices as dynamically engaging with the consumers, than traditional marketing communication channels. While; the use of 
guerilla tactics, and experiential campaigns, social media are becoming more established, best practices adjacent the strategic performance of those ever-evolving advertisement tools and their integration into an integrated marketing communication (IMC) methods has been not identified yet (Carrington, Neville, \& Whitwell, 2014).

Promotional camping of these famous garments and textile companies' develop strong awareness and loyalty in the mind of the target audience. Viral marketing is the unique tool of marketing that approach to the target audience within the limited resources capital. It's cost effective and dynamic tool of marketing helps to communicate maximum consumer around the world (Chang, 2015). Variations in consumers' like and dislike, the cognitive increase and enthusiasm strength them to act in various customs in purchasing clothing's products. The communication power of business with the target audience is the significant practice that enables the companies to design the marketing strategies as to win their perception of the consumers. Such type of activities would presents these two prevailing models e;g 'conviviality' 'transmission' of communication (Sabri, 2017).

\section{H1: Viral marketing has significant impact on the consumer buying behavior.}

\section{Ambient Marketing and Consumer Buying Behavior}

Ambient marketing approaches and marketing tools are playing their role as communication channels. Advertisement of any product is attracted to the consumer to buy the product. Most companies use the TV to deliver the clear message to the target audience as the maximum marketing can be captured (Waheed \& Jianhua, 2018). According to the study, the attention of a customer is the real allocation of intellectual resources, cognitive or pictorial, to the visible or intangible objects of the marketing and advertisement communication. While; the technology and internet drivers has been changed the era of consumer choice and selection of a brand, due to that the majority of consumers has been moved towards online shopping via their computers, smart phones and tablet consoles. Most of companies create their online social media accounts and websites, where they display their all product line with the complete description and standard, in short they are connected with consumers. The Ambient marketing characteristics are based on the elements of unconventionality; flexibility and ingenuity are often realistic by small and medium enterprises (SMEs), due to their prime fulfillment of these fundamentals (Gottschalk, 2018). It is not exceptional for the foundation of guerrilla marketing approaches to be the optimal application of scarce available capitals.

Concord Advertising, a British advertising and marketing agency focusing on outdoor campaigns, first used ambient advertising and marketing and advertising in 1996. The customers were requiring a few element unique for their campaigns, which made the corporation offer you with a few novel problem. The agency corporation commenced to place the advertisements on uncommon locations like at the flooring, petrol pump handles and on the decrease back of rest room doorways; this have become the feature of ambient advertising. But the uncommon locations are not the simplest element that defines ambient advertising and marketing. Ambient advertising and marketing furthermore uses an uncommon approach of execution which includes, for example, holography, role-plays and 
graffiti. According to Luxton and Drummond (2000), the definition of ambient marketing and advertising is: The placement of advertising in uncommon and sudden locations (area) often with unconventional strategies (execution) and being first or handiest Ad execution to achieve this (temporal). The key terms of Ambient advertising is newness, creativity and timing.

H2: Ambient marketing has significant impact on the consumer buying behavior.

\section{Stealth Marketing and Consumer Buying Behavior}

Guerrilla marketing is a cost effective and most admired advertising approach which is mostly used in product marketing. The dynamic practice used to in Guerrilla marketing it is Stealth Marketing that embraces several techniques such as celebrity marketing (Ahmad et al., 2014). An extensive range of appliances can be applied for the purpose of Viral Marketing communication it is rely on the extensive definition of VMC, including offline and online background, currently fifteen different VMC techniques are discovered as 'TellA-Friend', 'customer recommendations', 'E-cards', 'links', 'Search engines', 'Networks', 'Communities', 'Blogs', 'Wikis', 'Chat rooms', 'Online games or Advergames', 'Newsletters', 'Microsite', 'Free services', 'Affiliate programs' and 'Widgets' (Iqbal \& Lohdi, 2015; Karimi \& Naghibi, 2015). Street marketing events and pop-up shops have been established under the authority of 'unconventional communication' of advertisement and marketing. Several Italian companies are adopting that technique of promotion, because it is cost effective and easy to approach to the maximum consumers (Tam \& Khuong, 2015). Brand name or image is the vital driver for brand equity, it refers to the consumer's common perception and insight feeling about a product or service (Brand) and has an impact on consumer buying behavior.

Martin and Smith (2008) define stealth marketing because the implementation of advertising practices which fail to properly portray or explicitly present the relationship to the manufacturing organization or message sponsors. Kaikati and Kaikati (2004, pp.7nine) provide an reason behind that the popularity of the idea derives from 3factors: I) the accelerated complaint of advertising and advertising in the last a long time; II) the very fragmented customer marketplace that we enjoy in recent times which is becoming greater high priced and more tough and extra hard to reach no matter its length; and III) the advert-skipping potential purchasers received thru one of a kind technological devices. For the third problem the authors speak DVRs and TiVo but considering that their article got here out extra than a decade inside the past, the discussion even as it comes to television is not focused round recording gadgets however as an alternative around online streaming alternatives.

H3: Stealth marketing has significant impact on the consumer buying behavior. 


\section{Street Marketing and Consumer Buying Behavior}

The marketers have a need of dynamic inspiration of indication and a bunch of ideas as to give significantly in the guerrilla marketing strategy. That medium crowed know how to promote the brand with the consumer's positive intention (Kireev et al., 2016). Street marketing does not use only for the sale or promotion activities for a brand. But somewhere else it used for society's social norms, non-profitable organizations and socioeconomic activities (Kumar et al., 2017). Street marketing events and pop-up shops have been established under the authority of 'unconventional communication' of advertisement and marketing. Several Italian companies are adopting that technique of promotion, because it is cost effective and easy to approach to the maximum consumers). Brand name or image is the vital driver for brand equity, it refers to the consumer's common perception and insight feeling about a product or service (Brand) and has an impact on consumer buying behavior (Iqbal \& Lohdi, 2015).

Street events and movements capitalize on regions and performances to create Branded leisure. For street sports activities, temporary areas (e.g. Stands, pop-up stores, cafés, tiers, road shows and birthday celebration busses) and/or human beings (e.g.) entertainers, actors, musicians and road artists) are employed as sensory enjoy groups for clients to discover and have interaction with actual merchandise. Sony Ericsson employed crowds of actors to pose as travellers in New York City and in Los Angeles to invite humans in the streets to take their photograph with the organisation's new cell-smartphone digital camera. Some university students even bought advertising and marketing location on their foreheads to elevate cash for paying university expenses via developing full-size word of mouth (WOM) for the advertisers. Street moves are seeking out recommendation from the transformation of the cause or look of metropolis street furnishings and elements (e.g. Benches, road poles, elevators, kiosks, pedestrian crossings, potholes, bus shelters, statues and fountains) to dramatize and visualize the attributes of a product without revealing the economic nature. For instance, public fountains is determined on town's spouted water dyed crimson to resemble blood have been used to enhance the bloody brand of Dexter, the serial killer collection. It delivered a full-size type of avenue guerrilla advertising techniques to strain purpose market interest starting from Dexter's baby displayed on bibs and luggage at the Comic-Con occasion to a taxi stand with a custom art mosaic which encompass four,500 blood under microscope slides to form Dexter's photo.

H4: Street marketing has significant impact on the consumer buying behavior.

\section{Ambush Marketing and Consumer Buying Behavior}

The entrepreneurial and innovative essence of ambush marketing is typically practiced in the advertising and promotion behavior of the companies (Ghanbari \& Ghanbari, 2017). during the using of different media channels, slogans and tells the guerilla marketer both differentiates the (brand) business's ads as compare from its competitors in a dynamic position which extends its service and product particularly in the awareness for the projections. As the most companies start to realize the dynamic assessment of the Internet communication as a primary tool of the ambush, guerrilla marketing and communication 
platform, they are individually beginning to influence substitute approaches of advertising practices those are more efficient and money-making at dynamically engaging with the consumers, than traditional marketing communication channels (Robles, Chica, \& Cordón, 2016).

H5: Ambush marketing has significant impact on the consumer buying behavior.

Figure 1

Conceptual Framework

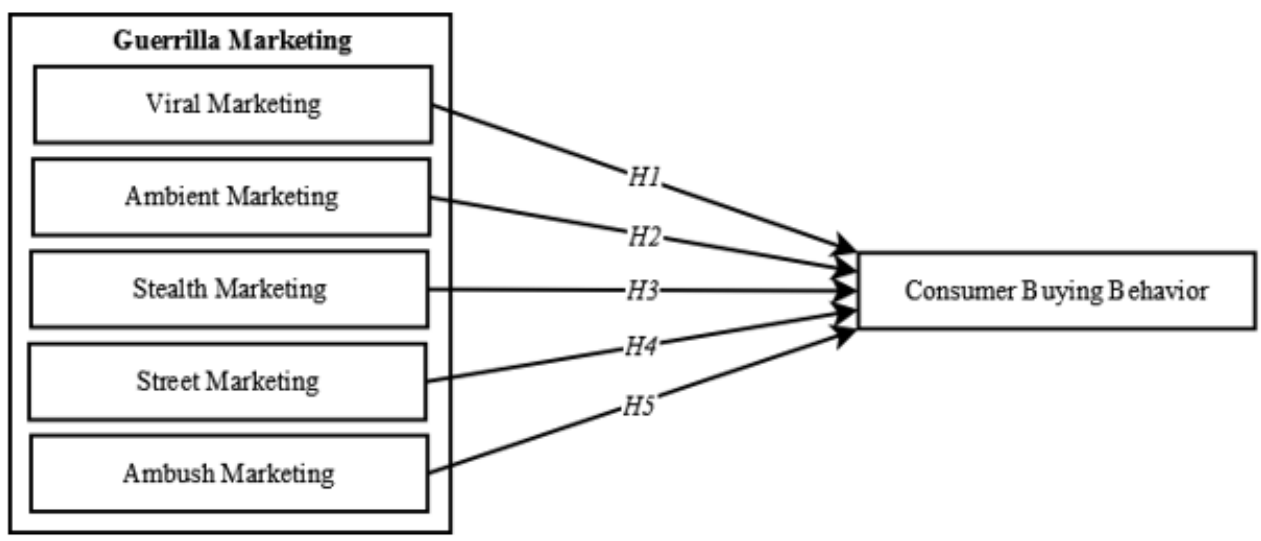

\section{Methods}

Quantitative approaches applied to know the impact of guerrilla marketing on consumer's buying behavior towards the clothing industry of Karachi, Pakistan. Primary data source is collected for this research study through close ended questionnaire based on Likert scale. Students and working class around the Karachi both are the part of total population group. Purposive sampling technique has been used to select participants for the study. A sample size of 247 respondents was included in the study as calculated from the sample size calculation estimator proposed by Soper (2018). The sample size has been calculated based on 17 observed variables 6 latent variables using significance level of 0.05. The study has used Covariance-Based Structural Equation Modeling (CB-SEM) as data analysis technique using SPSS-AMOS version 22. However, Cronbach's alpha for reliability analysis and principal component analysis were also employed for data analysis. Furthermore, the CB-SEM method included confirmatory factor analysis comprising construct validity, convergent validity and discriminant validity using Fornell and Larcker (1981) criterion, and path analysis for hypothesis-testing at 5 percent significance level. 


\section{Results and Findings}

\section{Pilot Study}

Prior to collect main study data, it has been recommended by Hazzi and Maldaon (2015) that undoubtedly, pilot study is a foundation of good research; however, it aids the quality of main study while improving feasibility of collecting comparatively larger sample size as in pilot study. Therefore, pilot study has been conducted using Cronbach's alpha reliability analysis. Therein, the study has found that internal consistency of the variables was ranged between 64.1 percent of ambient marketing and 89.1 percent of ambush marketing. However, these internal consistencies have achieved recommended threshold of 60 percent by Nunnally (1994). Hence, it has been manifested robust foundations for main study analysis.

\section{Data Screening}

Prior to data analysis, it is important to screen the main study data for missing values, univariate and multivariate outliers. In this regards, Tabachnick, Fidell, and Ullman (2007) proposed that standardized values ( $\mathrm{Z}$ score) of individual items below -3.29 or above +3.29 should be considered as univariate outliers and thereby, removed from the data. Similarly, Tabachnick et al. (2007) also proposed that Mahalanobis Distance (D2) $<0.001$ should be considered multivariate outliers and therein, removed from the data. Henceforth, the current study has collected total data of 289 from the sample (accessible) population while none missing values were found. However, 18 univariate outliers and 24 multivariate outliers were detected and then removed from the data. Therefore, the final data for analysis was remained of 247 sample responses.

\section{Demographic Profile of the Respondents}

Total 190 respondents $(76.9 \%)$ were male and remaining 57 respondents were female (23.1\%) amongst total 247 respondents. However, majority $(\mathrm{N}=109,44.1 \%)$ were between the age-group of 36 years to 45 years, whereas 58 respondents $(23.5 \%)$ were between 26 years and 35 years, 57 respondents $(23.1 \%)$ were 18 years to 25 years and only 23 respondents $(9.3 \%)$ were 46 years or above. Similarly, 185 respondents $(74.9 \%)$ have academic qualification of Master's degree while 38 respondents (15.4\%) were intermediate and 24 respondents $(9.7 \%)$ were Bachelors. Furthermore, 139 respondents $(56.3 \%)$ were residents of Gulistan-e-Jouhar, whereas 91 respondents (36.8\%) were residents of North Nazimabad and only 17 respondents (17\%) were residents of Gulshan-e-Iqbal town.

\section{Principal Component Analysis}

In the principal component analysis, it is prior good to estimate Kaiser-Meyer-Olkin (KMO) test of sampling adequacy and Bartlett's test of sphericity. Therein, Tabachnick et al. (2007) suggested that KMO test of sampling adequacy should be greater than 70 
percent while significance level of Bartlett's test of sphericity should be less than 0.001. Henceforth, following table 1 below provides result of KMO and Bartlett's tests.

\begin{tabular}{lll} 
Table 1 & & \\
KMO and Bartlett's Test & & \\
\hline Kaiser-Meyer-Olkin Measure of Sampling Adequacy & & 0.704 \\
Bartlett's Test of Sphericity & Approx. Chi-Square & 1589.7 \\
& df & 136 \\
& Sig. & 0 \\
\hline
\end{tabular}

It has been shown in table 1 that KMO measure of sampling adequacy was found 70.4 percent that is higher than the recommended threshold while Bartlett's test of sphericity found statistically significant at 99.9 percent confidence interval. Furthermore, following table 2 provides result of principal component analysis using Varimax rotation method and convergence of 25 values at cutoff value of 0.40 .

Table 2

Principal Component Analysis

\begin{tabular}{|c|c|c|c|c|c|c|}
\hline & \multicolumn{6}{|c|}{ Component } \\
\hline & 1 & 2 & 3 & 4 & 5 & 6 \\
\hline CBB3 & 0.877 & & & & & \\
\hline CBB2 & 0.877 & & & & & \\
\hline CBB1 & 0.776 & & & & & \\
\hline Stealth1 & & 0.875 & & & & \\
\hline Stealth2 & & 0.825 & & & & \\
\hline Stealth3 & & 0.743 & & & & \\
\hline Street3 & & & 0.852 & & & \\
\hline Street1 & & & 0.806 & & & \\
\hline Street2 & & & 0.732 & & & \\
\hline Viral2 & & & & 0.829 & & \\
\hline Viral1 & & & & 0.817 & & \\
\hline Viral3 & & & & 0.771 & & \\
\hline Ambient2 & & & & & 0.823 & \\
\hline Ambient3 & & & & & 0.790 & \\
\hline Ambient1 & & & & & 0.790 & \\
\hline Ambush1 & & & & & & 0.860 \\
\hline Ambush2 & & & & & & 0.849 \\
\hline Total & 2.223 & 2.181 & 2.125 & 2.118 & 1.975 & 1.787 \\
\hline$\%$ of Variance & 13.076 & 12.827 & 12.502 & 12.458 & 11.621 & 10.514 \\
\hline Cumulative \% & 13.076 & 25.903 & 38.405 & 50.863 & 62.484 & 72.998 \\
\hline
\end{tabular}

It has been recommended by Hair, Anderson, Babin, and Black (2010); Tabachnick et al. (2007) that factor loadings should be greater than 0.60 are considerable in PCA while total variance in percentage should be atleast 70 percent. Henceforth, the above table clearly showed that the study has comprehensively achieved recommended thresholds for PCA.

\section{Goodness-of-Fit (GoF)}

Following table 3 provides statistics of Goodness-of-Fit (GoF) indices for assessing model fitness in Confirmatory Factor Analysis (CFA) and Structural Equation Modeling (SEM) models. 
Table 3

Goodness of Fit (GoF) Model

\begin{tabular}{lccc}
\hline GoF Indices & Threshold & CFA & SEM \\
\hline Chi-Square (CMIN) & - & 157.6 & 286.03 \\
Degree of Freedom (DF) & - & 104 & 114 \\
CMIN/DF & $<3.00$ & 1.52 & 2.51 \\
Root Mean Square Residual (RMR) & $<0.08$ & 0.03 & 0.06 \\
Goodness of Fit Index (GFI) & $>0.85$ & 0.93 & 0.89 \\
Adjusted Goodness of Fit Index (AGFI) & $>0.85$ & 0.89 & 0.85 \\
Tucker-Lewis Index (TLI) & $>0.90$ & 0.95 & 0.86 \\
Comparative Fit Index (CFI) & $>0.90$ & 0.96 & 0.89 \\
Root Mean Square Error Approximation (RMSEA) & $<0.08$ & 0.05 & 0.08 \\
\hline
\end{tabular}

It has been proposed by Hair et al. (2010) that threshold for CMIN/DF should be atleast 3.00. Root Mean Square Residual (RMR) should be atleast 0.08, Tucker-Lewis Index (TLI) and Comparative Fit Index (CFI) should be higher than 0.90 and RMSEA should be atleast 0.08. While, Cole (1987) recommended that GFI and AGFI should be greater than 0.85 for considerable confirmatory factor analysis. Thus, the above table showed that the study has achieved thresholds for CMIN/DF, RMR, GFI, AGFI and RMSEA and thereby, the model fitness has been achieved.

\section{Confirmatory Factor Analysis}

There are two segments of structural equation modeling including Confirmatory Factor Analysis (CFA) and path analysis. While, before estimating relationship amid variables of the structural model, it is important to estimate confirmatory factor analysis. Thereby, following table 4 provides estimated results of confirmatory factor analysis.

\begin{tabular}{|c|c|c|c|c|c|}
\hline Construct & Items & Loadings & Prob. & AVE & CR \\
\hline \multirow[t]{3}{*}{ Consumer Buying Behavior } & CBB3 & 0.908 & 0.000 & 0.646 & 0.838 \\
\hline & CBB2 & 0.915 & 0.000 & & \\
\hline & CBB1 & 0.524 & 0.000 & & \\
\hline \multirow[t]{3}{*}{ Stealth Marketing } & Stealth1 & 0.706 & 0.000 & 0.594 & 0.813 \\
\hline & Stealth2 & 0.874 & 0.000 & & \\
\hline & Stealth3 & 0.720 & 0.000 & & \\
\hline \multirow[t]{3}{*}{ Street Marketing } & Street3 & 0.804 & 0.000 & 0.544 & 0.778 \\
\hline & Street1 & 0.802 & 0.000 & & \\
\hline & Street2 & 0.584 & 0.000 & & \\
\hline \multirow[t]{3}{*}{ Viral Marketing } & Viral2 & 0.710 & 0.000 & 0.549 & 0.783 \\
\hline & Viral1 & 0.857 & 0.000 & & \\
\hline & Viral3 & 0.640 & 0.000 & & \\
\hline \multirow[t]{3}{*}{ Ambient Marketing } & Ambient2 & 0.723 & 0.000 & 0.475 & 0.730 \\
\hline & Ambient3 & 0.659 & 0.000 & & \\
\hline & Ambient1 & 0.683 & 0.000 & & \\
\hline \multirow[t]{2}{*}{ Ambush Marketing } & Ambush1 & 0.787 & 0.000 & 0.663 & 0.797 \\
\hline & Ambush2 & 0.840 & 0.000 & & \\
\hline
\end{tabular}

With regards to recommended thresholds, (Hair et al., 2010; Tabachnick et al., 2007) suggested that item loadings should be atleast .50 and statistically significant at .95 confidence interval; composite reliability should be atleast .70 and average variance extracted 
should be greater than .50. However, Hair et al. (2010) particularly recommended that in case of slightly lower coefficient of AVE than .50 but composite reliability found higher than .70; then, the variable has certainly achieved considerable convergence on the basis of composite reliability. For ambush variable has two items which is explaining the construct as recommended by book Hair et al 2014. Henceforth, in the light of aforementioned discussion and recommendations, table 4 provided that item loadings were ranged between 0.524 of CBB1 and 0.915 of CBB 2while AVE was ranged between 0.475 of ambient marketing and 0.663 of ambush marketing; and finally, composite reliability was ranged between 73 percent of ambient marketing and 83.8 percent of consumer buying behavior. Thus, the study has considerably achieved construct and convergent validity.

\section{Discriminant Validity using Fornell and Larcker (1981) Criterion}

In order to estimate discriminant validity, the current study has used (Fornell \& Larcker, 1981) criterion as shown in the following table.

Table 5

Discriminant Validity using Fornell and Larcker (1981)Criterion

\begin{tabular}{lcccccc}
\hline Construct & CBB & Stealth & Street & Viral & Ambient & Ambush \\
\hline Consumer Buying Behavior & $\mathbf{0 . 8 0 4}$ & & & & & \\
Stealth Marketing & 0.200 & $\mathbf{0 . 7 7 1}$ & & & & \\
Street Marketing & 0.166 & 0.031 & $\mathbf{0 . 7 3 7}$ & & & \\
Viral Marketing & 0.023 & 0.080 & -0.575 & $\mathbf{0 . 7 4 1}$ & & \\
Ambient Marketing & 0.104 & 0.159 & 0.000 & 0.074 & $\mathbf{0 . 6 8 9}$ & \\
Ambush Marketing & 0.065 & -0.563 & 0.115 & -0.033 & -0.110 & $\mathbf{0 . 8 1 4}$ \\
\hline Note: Bold values are the square root AVE of their respective construct. &
\end{tabular}

According to Fornell and Larcker (1981), the square root of AVE for each variable should be greater than the corresponding correlation coefficients of all other variables to achieve discriminant validity. Henceforth, the above table clearly showed that all the variables in the structural model has achieved considerable discriminant validity using Fornell and Larcker (1981) criterion.

\section{Hypothesis Testing using Path Analysis}

Following table 6 provides result of hypothesis-testing using path analysis.

Table 6

Hypothesis-Testing using Path Analysis

\begin{tabular}{lcccc}
\hline & Estimate & Std. Dev. & T-Statistics & Prob. \\
\hline Stealth Marketing $\rightarrow$ Consumer Buying Behavior & 0.802 & 0.214 & 3.740 & $0.000^{* * *}$ \\
Street Marketing $\rightarrow$ Consumer Buying Behavior & 0.353 & 0.135 & 2.617 & $0.009^{* *}$ \\
Viral Marketing $\rightarrow$ Consumer Buying Behavior & 0.250 & 0.174 & 1.441 & 0.150 \\
Ambient Marketing $\rightarrow$ Consumer Buying Behavior & 0.134 & 0.139 & 0.963 & 0.336 \\
Ambush Marketing $\rightarrow$ Consumer Buying Behavior & 0.413 & 0.184 & 2.242 & $0.025^{*}$ \\
\hline$* * *$ P-value $<0.001 ; * *$ P-value $<0.01 ;$ *P-value $<0.05 ;$ NS: Not Significant & &
\end{tabular}

The above table showed that stealth marketing $(0.802, \mathrm{p}<0.001)$ and street marketing $(0.353, \mathrm{p}<0.01)$ have significant and positive impact on consumer buying behavior. This 
shows that awareness and use of stealth and street marketing positively enhances consumer buying behavior of the apparel customers in Karachi, Pakistan. Similarly, the results have shown that ambush marketing $(0.413, \mathrm{p}<0.05)$ significantly and positively influence consumer buying behavior. This also shows that ambush marketing is a significant determinant of guerrilla marketing that positively increases consumer buying behavior toward apparel customers of Karachi, Pakistan. However, viral marketing and ambient marketing have no significance relationship with consumer buying behavior.

\section{Discussion}

The study has achieved a better understanding towards the impact of guerrilla marketing on consumer buying behavior. The findings have shown a positive and significant impact of stealth, street and ambush marketing on consumer buying behavior. This shows that these three marketing tools are important determinants of guerrilla marketing that helps consumers to improve their behavior towards the apparel products. The findings are supported by previous studies in the case of stealth marketing. For instance, Iqbal and Lohdi (2015) have shown stealth marketing as significant determinant of guerrilla marketing and asserted that it is a rising and effective marketing tool used by firms to attract consumers. Similarly, Ahmad et al. (2014) have asserted that stealth marketing is an important and effective determinant of guerrilla marketing, which shows an increasing trend among firms to increase their consumer list.

In case of street marketing, the findings of the current study have shown a positive and significant impact towards consumer buying behavior. These findings have been supported positively by previous studies. For instance, Tam and Khuong (2015) have indicated that firms are using street marketing due to its attentive street graphics, memorable events, buzz, product placement and strange occurrences that are positively preferred among customers of every age group. Similarly, Dinh and Mai (2016) have shown that street marketing as a determinant of guerrilla marketing is perceived as fascinating, interesting, fun and cause more attention among the participants.

On the other hand, results have shown a positive but insignificant impact of viral and ambience marketing on consumer buying behavior. These findings have been supported by previous studies. For instance, the study conducted by Haryani, Motwani, and Sabharwal (2015) revealed that despite viral marketing is gaining its roots to become an effective guerrilla marketing tool, but it is still considered as a premature marketing tool among firms. Therefore, information about consumer buying behavior examined from viral marketing is in its infancy stage. Furthermore, the study has asserted that when customers receive viral message from their social network they sometimes express privacy and security concerns. Another important concern associated with viral marketing is the lack of control attached with viral marketing campaigns. The reason for this concern is that firms have no means to control the increase in spread of the message and the content of the transmission.

Viral marketing doesn't always have results in reaching its required objective because Negative sentiment about marketing campaign can also grow to be viral. It may reach saturation factor. It can be tough to create content it is likely to come to be viral, but also meets particular marketing desires. Especially in this case viral marketing doesn't work as 
get results from the targeted audience.

\section{Conclusion}

While analyzing the impact of guerrilla marketing on consumers' buying behavior specifically on clothing industry in Karachi this study asserted that stealth marketing has a positively significant impact upon consumer buying behavior as people in Karachi city of Pakistan don't pay much attention towards the authenticity of information they are receiving, they show interest in fake news, blogs, social networking sites etc. which can be used as the powerful tools of stealth marketing. Similarly, street marketing has positively significant effect on consumer buying behavior as people responds more on unconventional ways, like placing ads where people read, physically interacting with people, distributing samples and wrap advertising. Furthermore, viral marketing and ambient marketing has positively insignificant effect on consumer buying behavior as viral marketing does not always results in reaching its required objective and ambient marketing does not always encountered by target audience. Whereas, ambush marketing has a positively significant effect on consumer buying behavior as people in Karachi likes spending time at events such as cricket match, concerts, and food festivals etc.

\section{Managerial Implications}

On the basis of above results, study recommended managers working in the clothing industry of Karachi to attract people in large numbers and to create a buzz among the audience without letting people know that product is being marketed. Showcasing products brands through movies and sports, online forums, product promotions and showcase in malls and tasting events are some of the tactics which can be used to increase stealth marketing. Study further recommends managers to make efforts to increase street marketing as consumer responds productively to unconventional ways. Street marketing can be done through distribution of flyers or products, product animations, human animations, road shows, uncovered actions and event actions etc. We suggest managers to sponsor and invest on entertainment and sports events in order to market their product to a large number of people at a same time. On the basis of the findings of the study, there are some gaps in this domain that needs to be studied in the future like other large cities of Pakistan should also had included in the research. Sample size was also very small which might have given us unclear result. Lastly, we suggest researchers to study the impact of guerrilla marketing on other industries like on fast moving consumer goods.

\section{Limitations of the study}

With these limitations in mind, this study pursues to discover guerilla marketing from a theoretical viewpoint by developing a conceptualized understanding of guerilla marketing and examining the managerial implications of guerilla marketing for clothing industry. Without completely thoughtful the role, and development of guerilla marketing as a marketing communications strategy, it is impossible to truly assess the impact guerilla 
marketing. First, the advertising and marketing campaigns used in the test are completely out of doors campaigns, considering the reality that it's miles difficult to take a look at, as an example, a newspaper advert with an out of doors guerrilla advertising and marketing and advertising and marketing advertising and marketing campaign. Furthermore, the companies used are large, famous corporations, due to the fact we favored to ensure that everyone diagnosed the manufacturers, in order to get fairer effects.

Moreover, we've got were given selected to disregard low-rate impact and poor guerrilla advertising results within the completed test. However, the one's mind are defined inside the theoretical framework. Furthermore, the check disregards different out of doors factors that might have an effect at the results, such as if the respondents have visible the campaigns formerly. Items can be increases and analysis will be performed so that Ave increases according to Fornell and Larcker (1981) if ave is less than 0.5 but composite reliability is higher than 0.6 , the convergent validity of the construct is still adequate. 


\section{References}

Ahmad, N., Ahmed, R., Jahangir, M., Moghani, G., Shamim, H., \& Baig, R. (2014). Impacts of guerrilla advertising on consumer buying behavior. , 4(8), 45-52.

Carrington, M. J., Neville, B. A., \& Whitwell, G. J. (2014). Lost in translation: Exploring the ethical consumer intention-behavior gap. Journal of Business Research, 67(1), 2759-2767.

Chang, S.-H. (2015). The influence of green viral communications on green purchase intentions: The mediating role of consumers' susceptibility to interpersonal influences. Sustainability, 7(5), 4829-4849.

Cole, D. A. (1987). Utility of confirmatory factor analysis in test validation research. Journal of Consulting and Clinical Psychology, 55(4), 584.

Dempsey, E. (2016). Betting on guerrilla marketing: An investigation of the impact of outdoor guerrilla advertising by paddy power on the brand engagement of Irish male millennials (Unpublished doctoral dissertation). Dublin, National College of Ireland.

Fornell, C., \& Larcker, D. F. (1981). Structural equation models with unobservable variables and measurement error: Algebra and statistics. Sage Publications Sage CA: Los Angeles, CA.

Ghanbari, R., \& Ghanbari, A. R. (2017). The relationship between guerilla marketing and making decision to purchase max company's. Current Trends in Organizational Performance and Future Perspectives(1), 49-69.

Gottschalk, I. (2018). Consumer evaluation of ambient scent. International Journal of Retail \& Distribution Management, 46(6), 530-544.

Hair, J., Anderson, R., Babin, B., \& Black, W. (2010). Multivariate data analysis: A global perspective. NJ: Pearson Upper Saddle River.

Haryani, S., Motwani, B., \& Sabharwal, S. (2015). Factors affecting the consumers attitude towards internet induced viral marketing techniques. Arabian Journal of Business and Management Review, 5(4), 1-4.

Hazzi, O., \& Maldaon, I. (2015). A pilot study: Vital methodological issues. Business: Theory and Practice, 16(1), 53-62.

Iqbal, S., \& Lohdi, S. (2015). The impacts of guerrilla marketing on consumers' buying behavior: A case of beverage industry of Karachi. The International Journal of Business \& Management, 3(11), 1-7.

Karimi, S., \& Naghibi, H. S. (2015). Social media marketing (smm) strategies for small to medium enterprises (smes). International Journal of Information, Business and Management, 7(4), 86-98.

Kireev, V. S., Nekrasova, M. L., Shevchenko, E. V., Alpatskaya, I. E., Makushkin, S. A., \& Povorina, E. V. (2016). Marketing management as the realization process of research, production and sale activity of the enterprise. International Review of Management and Marketing, 6(6S), 228-234.

Kumar, V., Choi, J. B., \& Greene, M. (2017). Synergistic effects of social media and traditional marketing on brand sales: capturing the time-varying effects. Journal of the Academy of Marketing Science, 45(2), 268-288. 
Levinson, J. C. (1989). Guerrilla marketing attack: New strategies, tactics, and weapons for winning big profits for your small business. Houghton Mifflin Harcourt.

Mifsud, M. (2014). The effects of guerilla marketing on brand awareness (B.S. thesis). University of Malta.

Nunnally, J. C. (1994). Psychometric theory 3e. Tata McGraw-hill education.

Robles, J. F., Chica, M., \& Cordón, Ó. (2016). Incorporating awareness and genetic-based viral marketing strategies to a consumer behavior model. In 2016 IEEE Congress on Evolutionary Computation (CEC) (pp. 5178-5185).

Sabri, O. (2017). Does viral communication context increase the harmfulness of controversial taboo advertising? Journal of Business Ethics, 141(2), 235-247.

Schulze, C., Schöler, L., \& Skiera, B. (2014). Not all fun and games: Viral marketing for utilitarian products. Journal of Marketing, 78(1), 1-19.

Scott, D. M. (2015). The new rules of marketing and pr: How to use social media, online video, mobile applications, blogs, news releases, and viral marketing to reach buyers directly. John Wiley \& Sons.

Sharif, A., \& Butt, H. (2017). Online businesses and influence of e-marketing on customer satisfaction. Journal of Humanities Insights, 1(02), 86-90.

Soomro, Y. A. (2015). Antecedents of brand extension success in glocalization: A mediation and moderation analysis (Unpublished doctoral dissertation). Iqra University, Main campus, Karachi.

Soper, D. S. (2018). A-priori sample size calculator for structural equation models. Retrieved from http://www.danielsoper.com/statcalc3/calc.aspx

Tabachnick, B. G., Fidell, L. S., \& Ullman, J. B. (2007). Using multivariate statistics (Vol. 5). Pearson Boston, MA.

Tam, D. D., \& Khuong, M. N. (2015). The effects of guerilla marketing on Gen Y's Purchase Intention-A Study in Ho Chi Minh City, Vietnam. International Journal of Trade, Economics and Finance, 6(4), 191-198.

Velema, E., Vyth, E. L., Hoekstra, T., \& Steenhuis, I. H. (2018). Nudging and social marketing techniques encourage employees to make healthier food choices: A randomized controlled trial in 30 worksite cafeterias in The Netherlands. The American Journal of Clinical Nutrition, 107(2), 236-246.

Waheed, A., \& Jianhua, Y. (2018). Achieving consumers' attention through emerging technologies. Baltic Journal of Management, 13(2), 209-235. 